\title{
Parasites in harbour seals (Phoca vitulina) from the German Wadden Sea between two Phocine Distemper Virus epidemics
}

\author{
K. Lehnert $\cdot$ J. A. Raga $\cdot$ U. Siebert
}

Received: 25 September 2006 / Revised: 10 April 2007 / Accepted: 23 May 2007 / Published online: 22 May 2007

(C) Springer-Verlag and AWI 2007

\begin{abstract}
Parasites were collected from 107 harbour seals (Phoca vitulina) found on the coasts of Schleswig-Holstein, Germany, between 1997 and 2000. The prevalence of the parasites and their associated pathology were investigated. Eight species of parasites, primarily nematodes, were identified from the examined organs: two anisakid nematodes (Pseudoterranova decipiens (sensu lato), Contracaecum osculatum (sensu lato)) from the stomach, Otostrongylus circumlitus (Crenosomatidae) and Parafilaroides gymnurus (Filaroididae) from the respiratory tract, one filarioid nematode (Acanthocheilonema spirocauda) from the heart, two acanthocephalans, Corynosoma strumosum and C. semerme (Polymorphidae), from the intestine and an ectoparasite, Echinophthirius horridus (Anoplura, Insecta). Lungworm infection was the most prominent parasitological finding and secondary bacterial bronchopneumonia the most pathogenic lesion correlated with the parasites. Heavy nematode burdens in the respiratory tract were highly agerelated and more frequent in young seals. A positive correlation was observed between high levels of pulmonary infection and severity of bronchopneumonia. The prevalence of lungworms in this study was higher than in seals that died during the 1988/1989 Phocine Distemper Virus epidemic, and the prevalence of acanthocephalans and
\end{abstract}

Communicated by H.-D. Franke.

K. Lehnert $(\bowtie) \cdot$ U. Siebert

Forschungs- und Technologiezentrum Westkueste,

Hafentoern 1, 25761 Buesum, Germany

e-mail: lehnert@ftz-west.uni-kiel.de

\section{J. A. Raga}

Marine Zoology Unit, Cavanilles Institute of Biodiversity and Evolutionary Biology, University of Valencia, P.O. Box 22085, 46071 Valencia, Spain heartworms had decreased compared to findings from the first die-off.

Keywords Harbour seal · Parasites · Lungworms · Respiratory tract $\cdot$ Pathology

\section{Introduction}

The assessment of the health status of harbour seals (Phoca vitulina) in German waters has been undertaken since the seal die-off in 1988/1989. While searching for the cause of the epizootic in the Wadden Sea, detailed necropsies were performed on seals for the first time. It became obvious that a thorough knowledge of the parasitism in seals was needed to avoid misinterpretation of the necropsy findings. Later, Phocine Distemper Virus (PDV) was identified as the cause of the first epizootic (Kennedy 1990) as well as for the second die-off in 2002 (Müller et al. 2002). During both epizootics, the seal population in the Wadden Sea was significantly reduced by $40-60 \%$ (Härkönen et al. 2006). Since 1989, various research projects have been established to monitor the population dynamics and health status of seals. Special attention has been given to parasites as major agents of infection, but data on parasites of seals from the Wadden Sea originate mostly from seals that died during the 1988/1989 PDV epidemic (Borgsteede et al. 1991; Claussen et al. 1991; Lunneryd 1992a). Neither before nor after the first epizootic have systematic investigations of the parasitation of seals in the North Sea been performed. Parasitic infections in seals have been found in the respiratory and alimentary tract, heart and on the fur (Raga 1992). Infections with lungworms are often associated with secondary bacterial infections and are known to seriously affect the health of young seals (Bergeron et al. 1997). High 
intensities of lung nematodes cause obstruction of the airways, impede diving ability and are a common cause of mortality (Dailey 1970). Gastrointestinal parasites may cause ulcers and inflammation and even perforation of the intestinal wall (Bergmann and Olsson 1985). In this study, special attention was paid to lesions caused by parasites. The prevalence of parasite species (Bush et al. 1997) and level of infection in hosts from different age classes were compared and correlated with bronchopneumonia and gastritis. The aims of this study were to determine the influence of parasites on the health status of seals unbiased by PDV and to analyse changes in the prevalence and level of infections over time.

\section{Methods}

Samples originated from 107 harbour seals collected along the coasts of Schleswig-Holstein, Germany, between 1997 and 2000. Of these, 51 seals were found dead and 56 animals were killed because of serious illness by a shot to the head by authorized national park rangers. The majority of the carcasses were stored at $-20^{\circ} \mathrm{C}$ until necropsy; five were dissected while fresh. Necropsies were performed according to standard laboratory methods, as described by Siebert et al. (2001) for harbour porpoises and were modified for seals. All organs were examined macroscopically and histologically. Microbiological, serological and virological investigations were also carried out (U. Siebert et al. unpublished data). Parasites were collected during necropsies, preserved in $70 \%$ ethanol and identified microscopically after preparation in lactophenol. The levels of parasite infection and pathological lesions were evaluated separately from each other and judged subjectively (Wünschmann et al. 2001) during necropsies and later confirmed by histology. Macroscopic parasite infections were determined semiquantitatively: no $=$ no parasites, mild $=$ mild infection, moderate $=$ moderate infection, severe $=$ severe infection . Pathological lesions in organs infected with parasites were recorded and evaluated as no $=$ no inflammation, no lesion, mild = focal mild inflammatory lesions, moderate $=$ multifocal moderate inflammatory lesions or severe $=$ multifocal severe inflammatory lesions (Siebert et al. 2001). Levels of parasitic infection (no, mild, moderate and severe) were correlated with pathological lesions (no, mild, moderate and severe) in the infected organs. In 91 seals (85\%), age was determined by tooth sectioning from cementum growth layers (Mansfield and Fisher 1960) and all seals were divided into age classes: "age class 0 " [born and deceased in the same year ( $\sim 6$ months)]; "age class 1 " [seal born the previous year (up to 18 months)]; and "age class 2" (animals $>18$ months). Non-parametric tests were chosen according to Siegel and Castellan (1988). Exact tests were calculated when small samples required their use (Mundry and Fischer 1998), and two-tailed $P$-values are indicated throughout. To interpret the results of multiple tests, two approaches were used: first, a binomial test was used to test if the number of significant $P$-values corresponded to chance expectation (5\%) (Cross and Chaffin 1982) and, secondly, Fisher's Omnibus-test was applied (Haccou and Meelis 1994) when Mann-Whitney $U$-tests (MW- $U$ ) were calculated using SPSS (11.0.1). For example, shot versus stranded and age classes 0,1 and 2 were factors by which the data were split (age class 2 shot animals were excluded due to small sample size). Tests were then calculated for each parameter (level of lungworm infection, level of pathological lesions in the lung, level of parasite infection in the heart, level of parasite infection in the stomach, level of pathological lesions in the stomach, level of parasite infection in the intestine, level of pathological lesions in the intestine, level of ectoparasite infection and level of infection in pulmonary blood vessels) separately. Hence, five data sets (combinations of levels of factors) times nine parameters result in $45 \mathrm{MW}-U$ tests and $45 P$-values. Parasite infections in the lung and in pulmonary blood vessels were grouped together after these tests (respiratory tract; see Table 2), because they consisted of the same species. Generalized linear (GLM) and linear mixed effect (LME) models were performed using the statistical platform R (2.4.1). Parasite fauna and prevalence from the 1988/1989 PDV epidemic published by Borgsteede et al. (1991), Claussen et al. (1991), Lunneryd (1992a, 1992b) and Strauss et al. (1991) were compared to the data from this study.

\section{Results}

Table 1 shows the age and sex distribution of shot and dead stranded seals. Eight species of parasites were identified from the samples collected, this being the first geographical record of $P$. gymnurus (Filaroididae; Metastrongyloidea) from Schleswig-Holstein (see Table 2). Five species were nematodes: two anisakid nematodes (Pseudoterranova decipiens and Contracaecum osculatum) from the stomach and two nematodes (Otostrongylus circumlitus (Crenosomatidae) and Parafilaroides gymnurus (Filaroididae)) from the respiratory tract. Acanthocheilonema spirocauda (Filarioidae) was found in the heart. In addition, two acanthocephalans (Corynosoma strumosum and Corynosoma semerme) belonging to the Polymorphidae were found in the intestine and one ectoparasite (Echinophthirius horri$d u s$ ), Anoplura, was collected from the skin and fur (Fig. 1; Table 2). Neither intestinal nor liver flukes (Trematoda) and no cestodes were found in this study.

No differences in the levels of infection and associated pathological lesions were found between the sexes $\left(\chi^{2}=62.7\right.$, 
Table 1 Age and sex distribution of 51 stranded and 56 shot seals

\begin{tabular}{|c|c|c|c|c|c|}
\hline \multirow[t]{2}{*}{ Age class } & \multicolumn{2}{|l|}{ Shot } & \multicolumn{2}{|c|}{ Stranded } & \multirow[t]{2}{*}{ Total } \\
\hline & Male & Female & Male & Female & \\
\hline 0 & 17 & 11 & 7 & 8 & 43 \\
\hline 1 & 14 & 11 & 13 & 7 & 45 \\
\hline 2 & $2^{\mathrm{a}}$ & $1^{\mathrm{a}}$ & 10 & 6 & 19 \\
\hline
\end{tabular}

${ }^{a}$ Shot seals from age class 2 were not included in some statistical tests due to small sample size

$d f=90, P=0.987)$, and no differences in the levels of infection and associated pathological lesions between stranded and shot seals were found $\left(\chi^{2}=57.7, d f=108\right.$, $P=0.999$ ) (Fig. 1; Table 3). So these groups were lumped for further statistical testing. With regard to the age distribution of stranded and shot seals, more age class 0 and 1 seals were shot due to serious illness $\left(\chi^{2}=13.6, d f=2\right.$, $P<0.01$ ). Older seals (age class 2 ) were mostly found dead (see Table 1).

The prevalence of parasites in seals from the Wadden Sea in the study period differed significantly (Pearson's chisquare test, four values $P<0.05$ ) from findings presented in previous studies conducted during the first PDV epidemic in 1988/1989 (Table 5).

Parasites in the respiratory tract

A total of 81 seals $(76 \%)$ exhibited a parasitic infection of the respiratory tract with metastrongyloid nematodes (Table 2). Infections of $O$. circumlitus and $P$. gymnurus were often mixed and both species were grouped together for the correlation analysis. When pooling all age classes and sexes, both shot and stranded seals, a highly significant positive correlation $(P<0.05)$ was found between levels of lungworm infection and severity of bronchopneumonia (GLM: $r^{2}=0.41$ ). Bronchopneumonia, as a secondary bacterial infection associated with lungworms, was found to be the cause of death or severe illness leading to death in 56 seals (Table 4). The type of bronchopneumonia associated with lungworms varied between suppurative, suppurative-necrotizing and granulomatous bronchopneumonia with or without abscesses. Age class $0(n=43)$ and age class $1(n=45)$ seals showed a high prevalence (77 and 93\%) of lungworm infections. As to the levels of parasitic infection in the respiratory tract of seals from different age classes, age class 0 and age class 1 seals were more severely infected than age class 2 seals (Fig. 2) (8 KruskalWallis $H$-tests, separately for each combination of sex and shot $/$ stranded. $\left.\chi^{2}=60.7, d f=16, P<0.0001\right)$. Only one seal from age class 2 suffered from a moderate lungworm infection and four animals from a mild infection. Considering the levels of pulmonary nematode infection and associated lesions in shot and stranded animals, no clear difference between shot and stranded animals was observed $\left(\chi^{2}=27.5, d f=24, P=0.28\right)$.

Parasites in the heart

A total of 13 seals (12\%) were infected with nematodes in the heart and pulmonary arteries: three animals were severely infected, two moderately and eight mildly. Six harboured Acanthocheilonema spirocauda, two of them being severely infected in the right chamber and atrium. One stranded seal was severely infected in the right atrium and had a perforation $\left(2 \times 3 \mathrm{~mm}^{2}\right)$ of the atrium and $15 \mathrm{ml}$

Table 2 Parasite species, location and prevalence in 51 stranded and 56 shot seals

\begin{tabular}{|c|c|c|c|c|}
\hline \multirow[t]{2}{*}{ Parasites } & \multirow[t]{2}{*}{ Distribution } & \multicolumn{3}{|c|}{ Prevalence \% $(n)$} \\
\hline & & Stranded & Shot & Total \\
\hline \multicolumn{5}{|l|}{ NEMATODA } \\
\hline Otostrongylus circumlitus & Bronchi, pulmonary blood vessels, heart & $67(34)$ & $84(47)$ & $76(81)$ \\
\hline Parafilaroides gymnurus & Bronchioles, lung tissue, nodules & $n e^{a}$ & $n e^{a}$ & $n e^{a}$ \\
\hline Pseudoterranova decipiens & Stomach & $65(33)$ & $68(38)$ & $66(71)$ \\
\hline Contracaecum osculatum & Stomach & $n e^{a}$ & $\mathrm{ne}^{\mathrm{a}}$ & $n e^{a}$ \\
\hline Acanthocheilonema spirocauda & Right chamber, right atrium, heart & $6(3)$ & $5(3)$ & $6(6)$ \\
\hline \multicolumn{5}{|l|}{ ACANTHOCEPHALA } \\
\hline Corynosoma semerme & Intestine & $2(1)$ & $0(0)$ & $1(1)$ \\
\hline Corynosoma strumosum & Intestine & $27(14)$ & $20(11)$ & $23(25)$ \\
\hline \multicolumn{5}{|l|}{ INSECTA } \\
\hline Echinophthirius horridus & Skin, fur & $8(4)$ & $0(0)$ & $4(4)$ \\
\hline
\end{tabular}

ne not estimated

${ }^{\text {a }}$ Was not attempted, because not all individuals were recovered from lungs and digestive tract 


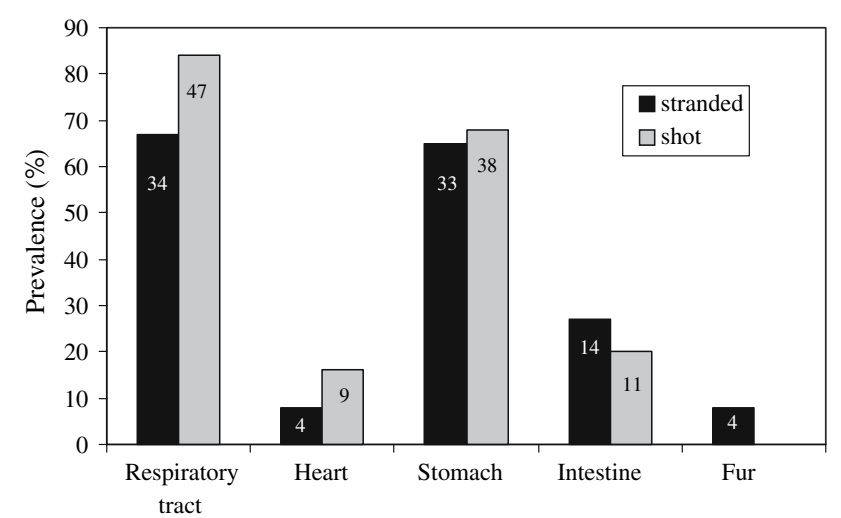

Fig. 1 Phoca vitulina. Prevalence of parasitic infections in respiratory tract, heart, stomach, intestine and fur in stranded $(n=51)$ and shot $(n=56)$ seals from the German Wadden Sea between 1997 and 2000. Numbers in columns are the exact numbers of the shot and stranded seals infected in different organs

of coagulated blood in the pericardium. This condition was determined to have been the cause of death. One animal was moderately infected with $A$. spirocauda in the right chamber, two showed a mild infection in the right chamber and one of them additionally in the right atrium. Eight seals had mild $O$. circumlitus infections in the heart. All of those exhibited an additional infection with lungworms in the respiratory tract and/or pulmonary blood vessels. One seal had a mixed and mild infection of $A$. spirocauda and $O$. circumlitus in the heart. Animals infected with A. spirocauda were from age class $0(n=2)$ or age class $1(n=4)$.

Parasites in the stomach

A total of 71 seals $(66 \%)$ were infected with stomach worms. The majority (55 individuals) had a mild infection. Thirteen animals were infected moderately, only three animals showed a severe infection. Stomach parasites were primarily Pseudoterranova decipiens (sensu lato), although some adult specimens of Contracaecum osculatum (sensu lato) were found. In this study, 18 seals showed gastritis, 17 of them being infected with stomach worms. The character of gastritis in animals with stomach nematodes was in most cases diffuse catarrhalic and lymphocytic gastritis. Only one dead stranded female had a $1 \mathrm{~cm}$ ulcer in the stomach associated with stomach worms. A weak positive correlation between the level of stomach infection and gastritis was shown (all eight correlation coefficients positive, sign test $<0.008)$.

Parasites in the intestine

A total of 25 seals (23\%) were infected with acanthocephalans in the intestine. Corynosoma strumosum was found in all seals, but $C$. semerme occurred only rarely (one animal) and in a mixed infection. Twenty seals exhibited a mild infection, four a moderate and only one a severe infection. Of the animals studied, 16 had enteritis, but only 8 of them were infected with acanthocephalans. The nature of the enteritis, when coinciding with acanthocephalans, was mostly a mild diffuse catarrhalic, lymphocytic plasmacellular enteritis. From 1997 to 2000, a significant increase in the level of the infection in the intestine was observed (LME: random factor: age group: $P($ time $)<<0.05)$.

\section{Ectoparasites}

Four stranded seals were infected with Echinophthirius horridus, the seal louse, belonging to the Anoplura, Insecta. In two animals, the infestation was severe, one seal was moderately infested and one animal mildly infested. None of the infested seals were infected with Acanthocheilonema spirocauda, for which E. horridus is believed to be an intermediate host (Geraci et al. 1981). One infected seal was age class 2 and three were age class 1 . One severely infested seal (1 year old) was found to have died of anaemia.

\section{Discussion}

Infections with metastrongyloid lungworms were the most prominent parasitological finding in this study. Lungworm infection and associated secondary bacterial infections leading to bronchopneumonia were also major pathological findings leading to death (natural or by shooting) in more than half of the seals (Table 4 ). The lesions produced by nematodes can obviously enable the entry of bacteria or fungi (Wünschmann et al. 1999).

Our data show that shot seals were diseased and eventually would have died shortly after from natural causes, if they had not been shot. The absence of flukes and cestodes in this study suggests a shift in either prey species or a change in immune status of seals in the Wadden Sea.

Lungworm infection in seals in this study was highly age related, seals from age classes 0 and 1 were especially affected by heavy burdens of nematodes in the respiratory tract. In contrast, the harbour porpoise (Phocoena phocoena) calving in the same habitat does not exhibit strong age-dependent lungworm infections (Lehnert et al. 2005), although lungworm species of harbour porpoises and harbour seals are quite closely related (Carreno and Nadler 2003) and the lifecycles therefore may be similar (K. Lehnert et al. unpublished data). The differences might be due to the longer lactation period of porpoises of about 8 months (Møhl-Hansen 1954). Harbour seal pups, weaned after $\sim 4$ weeks (Ross et al. 1994), may have a suppressed or still not completely developed immune system (Lalancette et al. 2003), which could result in pups being more susceptible to 
Table 3 Distribution of parasites and associated pathological findings between 51 stranded and 56 shot seals

\begin{tabular}{llll}
\hline Findings & \multicolumn{3}{l}{ Prevalence in affected seals \% $(n)$} \\
\cline { 2 - 4 } & Stranded & Shot & Total \\
\hline Pulmonary nematodiasis & $67(34)$ & $84(47)$ & $76(81)$ \\
Suppurative, or suppurative-necrotizing & $69(35)$ & $79(44)$ & $74(79)$ \\
$\quad$ bronchopneumonia & & & \\
Cardiac luminal nematodiasis & $8(4)$ & $16(9)$ & $12(13)$ \\
Perforation of the pericard & $2(1)$ & $0(0)$ & $1(1)$ \\
Gastric nematodiasis & $65(33)$ & $68(38)$ & $66(71)$ \\
Gastritis & $16(8)$ & $18(10)$ & $17(18)$ \\
Intestinal parasitosis & $27(14)$ & $20(11)$ & $23(25)$ \\
Enteritis & $18(9)$ & $13(7)$ & $15(16)$ \\
Skin & $8(4)$ & $0(0)$ & $4(4)$ \\
\hline
\end{tabular}

Table 4 Causes of death in 51 stranded seals and severe illness leading to death in 56 shot seals

\begin{tabular}{|c|c|c|c|}
\hline \multirow{2}{*}{$\begin{array}{l}\text { Fatal conditions } \\
\text { Lesion }\end{array}$} & \multicolumn{3}{|c|}{ Prevalence in affected seals \% $(n)$} \\
\hline & Stranded & Shot & Total \\
\hline Endoparasitosis & $6(3)$ & $9(5)$ & $7(8)$ \\
\hline Bronchopneumonia & $43(22)$ & $61(34)$ & $52(56)$ \\
\hline Intestinal dislocation & $10(5)$ & $0(0)$ & $5(5)$ \\
\hline Dermatitis & $2(1)$ & $4(2)$ & $3(3)$ \\
\hline Anaemia & $2(1)$ & $0(0)$ & $1(1)$ \\
\hline Perforation of atrium & $2(1)$ & $0(0)$ & $1(1)$ \\
\hline Not diagnosed & $22(11)$ & $9(5)$ & $15(16)$ \\
\hline Others $^{\mathrm{a}}$ & $10(5)$ & $9(5)$ & $18(10)$ \\
\hline
\end{tabular}

${ }^{a}$ Include single cases of: dystocia, trauma, keratitis, myositis and sepsis

infective larvae from prey items. We conclude that some uninfected pups from age class 0 were probably not infected because they died before they were weaned. Different feeding habits of the different age classes could also account for higher infection rates in young seals. The stimulation of immunity seems to be responsible for the statistically significant higher infection of lungworms in young age classes compared to adults (Claussen et al. 1991). It is known that repeated infections with lungworms in cattle stimulate a highly protective immunity (Pflugfelder 1977).

The high prevalence of parasitic infection in the respiratory tract $(76 \%)$ recorded in this study was not found during the 1988/1989 epidemic by Claussen et al. (1991), who recorded a prevalence of $26 \%$ in seals from Lower Saxony, and by Borgsteede et al. (1991), who only found a prevalence of 6\% in waters around The Netherlands.

In this study, A. spirocauda was predominantly found in young seals and did not impact their health, which supports the observation by Lunneryd (1992a), who reported its presence mainly in young animals without affecting their condition. Compared to findings from the first PDV epidemic (25\% prevalence found by Borgsteede et al. 1991 and $32 \%$ prevalence found by Claussen et al. 1991), the occurrence of A. spirocauda in seals from the Wadden Sea has decreased. Otostrongylus circumlitus presumably migrates to the heart via the bloodstream through pulmonary blood vessels or via a postmortem migration before the carcasses were frozen. The prevalence of parasitic infection in the stomach $(66 \%)$ differed from that found by other authors during the first PDV epidemic in 1988 (88\% found by Claussen et al. 1991, 59\% found by Borgsteede et al. 1991, 64-100\% by Lunneryd 1992b and 36-98\% found by Lick 1991). P. decipiens is clearly more abundant in harbour seals than $C$. osculatum, as found by Lick (1991).

The prevalence of acanthocephalans (23\%) was low compared to $95 \%$ in seals from waters of Lower Saxony in 1988/1989 (Strauss et al. 1991) and 70\% in seals from the Dutch coast during 1988 (Borgsteede et al. 1991). An increasing trend in acanthocephalan infection levels was found during the study period. Gastrointestinal parasite species did not pose a serious health threat to seals in the Wadden Sea and seldom occurred in high levels of infection. No clear age-related increase in infections was seen, contrary to findings by Strauss et al. (1991) and no strong correlation between parasites and gastrointestinal inflammation was found.

E. horridus prevalence (4\%) on harbour seals was very low compared to the $39 \%$ found by Thompson et al. (1998) in the Moray Firth, off Scotland. However, in studies from The Netherlands (Borgsteede et al. 1991), Lower Saxony (Claussen et al. 1991; Strauss et al. 1991) and the KattegatSkagerrak (Lunneryd 1992a), no ectoparasites have been reported at all. Although specimens can be washed off after the death of their host and might have been missed during necropsy, the last record from the Wadden Sea was mentioned by Zimmermann and Nebel (1975), indicating that 
Table 5 Prevalence \% ( $n$ ) of harbour seals infected with parasite species as examined in previous studies

\begin{tabular}{|c|c|c|c|c|c|}
\hline Species & $\begin{array}{l}\text { Borgsteede } \\
\text { et al. }(1991) \\
(n=94)\end{array}$ & $\begin{array}{l}\text { Strauss } \\
\text { et al. }(1991) \\
(n=110)\end{array}$ & $\begin{array}{l}\text { Claussen } \\
\text { et al. }(1991) \\
(n=115)\end{array}$ & $\begin{array}{l}\text { Lunneryd }(1992 \mathrm{a}, 1992 \mathrm{~b}) \\
(n=158 ; n=146)\end{array}$ & $\begin{array}{l}\text { This study } \\
(n=107)\end{array}$ \\
\hline Otostrongylus circumlitus & $6(6)$ & $\mathrm{x}$ & $26(30)$ & $0(0)$ & $76(81)$ \\
\hline Acanthocheilonema spirocauda & $25(23)$ & $\mathrm{x}$ & $32(37)$ & $11(18)$ & $6(6)$ \\
\hline Pseudoterranova decipiens & $59(55)$ & $\mathrm{x}$ & $88(101)$ & $\mathrm{x}$ & $66(71)$ \\
\hline Corynosoma strumosum & $70(66)$ & $95(104)$ & $\mathrm{x}$ & $32(46)$ & $23(25)$ \\
\hline Cryptocotyle lingua & $75(70)$ & $71(78)$ & $\mathrm{x}$ & $\mathrm{x}$ & $0(0)$ \\
\hline Phagicola septentrionalis & $66(62)$ & $36(39)$ & $\mathrm{x}$ & $\mathrm{x}$ & $0(0)$ \\
\hline Diphyllobothrium sp. & $9(8)$ & $32(35)$ & $\mathrm{x}$ & $0(0)$ & $0(0)$ \\
\hline
\end{tabular}

$\mathrm{x}=$ not investigated

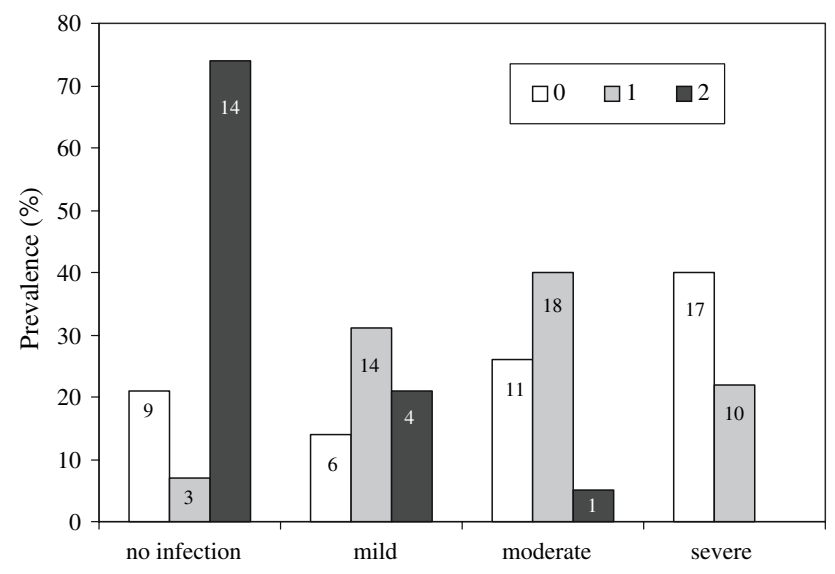

Fig. 2 Phoca vitulina. Prevalence of levels (no, mild, moderate and severe) of lungworm infection in harbour seals in age classes 0,1 and 2 from the German Wadden Sea between 1997 and 2000 ( $n=107)$. For definition of age classes see section M\&M. Numbers in columns depict the exact number of seals per age class

the prevalence of $E$. horridus has strongly decreased over recent decades. E. horridus probably carries low intensities of larval stages of $A$. spirocauda, which would account for the lack of $A$. spirocauda infection in seals infested with E. horridus (Conlogue and Ogden 1980). No lice and no A. spirocauda were found in 1999, which might underline the fact that they normally occur together (Table 5).

The considerable variations in earlier data indicate a high spatial, individual or method-based heterogeneity. Repeated parasitological surveys are needed to evaluate the fauna and prevalence over periods of time and in relation to the health status of harbour seals.

\section{Conclusions}

Metastrongyloid nematodes in the respiratory tract play a major role in causing disease and mortality in the Wadden Sea seal population, contrary to all other parasite species that were not found to be a major health threat to the seals.
The parasite fauna and their prevalence differed significantly from data recorded during the first epizootic. While a much higher lungworm prevalence was found in this study, there are decreasing trends observed in the prevalences of acanthocephalan and heartworm infections in comparison with studies from the 1988/1989 epizootic, as well as an increase in the intestinal parasitation over the study period. Evaluating data from seals that died during the second PDV epidemic in 2002 in the Wadden Sea might show if the animal's immune system is suppressed by the virus and if it has any influence on the susceptibility of harbour seals to parasites.

Acknowledgements The authors thank those who helped to collect seals on the German coasts and those who helped to assess the pathological findings. We thank Dr. Kai Abt for the age determination and Dr. Roger Mundry and Sven Adler for their support in working the statistics. The health monitoring of seals in Schleswig-Holstein was funded by the Ministry for Environment, Nature Conservation and Agriculture of Schleswig-Holstein.

\section{References}

Bergeron E, Measures N, Huot J (1997) Lungworm (Otostrongylus circumlitus) infections in ringed seals (Phoca hispida) from eastern Arctic Canada. Can J Fish Aquat Sci 54:2443-2448

Bergmann A, Olsson M (1985) Pathology of Baltic grey seal and ringed seal females with special reference to adrenocortical hyperplasia: is environmental pollution the cause of a widely distributed disease syndrome? Finn Game Res 44:47-62

Borgsteede FMH, Bus HGJ, Verplanke JAW, Van der Burg WPJ (1991) Endoparasitic helminths of the harbour seal, Phoca vituli$n a$, in The Netherlands. Neth J Sea Res 28:247-250

Bush AO, Lafferty KD, Jeffrey ML, Shostak AW (1997) Parasitology meets ecology on its own terms: Margolis et al. revisited. J Parasitol 83(4):575-583

Carreno RA, Nadler SA (2003) Phylogenetic analysis of the Metastrongyloidea (Nematoda: Strongylida) inferred from ribosomal RNA gene sequences. J Parasitol 89(5):965-973

Claussen D, Strauss V, Ising S, Jäger M, Schnieder T, Stoye M (1991) The helminth fauna of the common seal (Phoca vitulina vitulina, Linne, 1758) of the Wadden Sea in lower Saxony. J Vet Med 38:649-656 
Conlogue GJ, Ogden JA (1980) Pediculosis and severe heartworm infection in a harbour seal. Vet Med Small Anim Clinician 75:1184-1186

Cross EM, Chaffin WW (1982) Use of the binomial theorem in interpreting results of multiple tests of significance. Educ Psychol Meas 42:25-34

Dailey MD (1970) The transmission of Parafilaroides decorus (Nematoda: Metastrongyloidea) in the California sea lion (Zalophus californicus). Proc Helm Soc Wash 37(2):215-222

Geraci JR, Fortin JF, StAubin DJ, Hicks BD (1981) The seal louse, Echinophthirius horridus: an intermediate host of the seal heartworm, Dipetalonema spirocauda (Nematoda). Can J Zool 59(7):1457-1459

Haccou P, Meelis E (1994) Statistical analyses of behavioural data. University Press, Oxford

Härkönen T, Dietz R, Reijinders P, Teilmann J, Thompson P, Harding K, Hall A, Brasseur S, Siebert U, Goodman SJ, Jepson PD, Rasmussen TD (2006) Review of the seal epizootics in Europe. Dis Aquat Org 68:115-130

Kennedy S (1990) A review of the 1988 European seal morbillivirus epizootic. Vet Rec 127:563-567

Lalancette A, Morin Y, Measures L, Fournier M (2003) Contrasting changes of sensitivity by lymphocytes and neutrophils to mercury in developing grey seals. Dev Comp Immunol 27(8):735-747

Lehnert K, Raga JA, Siebert U (2005) Macroparasites in harbour porpoises (Phocoena phocoena) from German and Norwegian waters. Dis Aquat Org 64(3):265-269

Lick R. (1991) Untersuchungen zu Lebenszyklus (Krebse-Fische-marine Säuger) und Gefrierresistenz anisakider Nematoden in Nordund Ostsee. Berichte an das Institut für Meereskunde an der Christian-Albrechts-Universität Kiel, Nr. 218

Lunneryd SG (1992a) Dipetalonema spirocauda (Leidy) (Nematoda) and Corynosoma strumosum (Rudolphi) (Acanthocephala) infection in harbour seal from the Kattegat-Skagerrak and the Baltic. Sarsia 76:267-271

Lunneryd SG (1992b) Anisakid nematodes in the harbour seal Phoca vitulina from the Kattegat-Skagerrak and the Baltic. Ophelia 34(2):105-115

Møhl-Hansen U (1954) Investigations on reproduction and growth of the porpoise (Phocaena phocaena $[\mathrm{L}]$ ) from the Baltic. Vidensk Medd dansk naturh Foren 116:369-393
Mansfield AW, Fisher HD (1960) Age determination in the harbour seal, Phoca vitulina $\mathrm{L}$. Nature 186:92-93

Müller G, Wohlsein P, Beineke A, Haas L, Greiser-Wilke I, Siebert U, Fonfara $\mathrm{S}$, Harder $\mathrm{T}$, Stede $\mathrm{M}$, Gruber $\mathrm{AD}$, Baumgärtner $\mathrm{W}$ (2002) Phocine distemper in German seals. Emerg Infect Dis 10(4):723-725

Mundry R, Fischer J (1998) Use of statistical programs for nonparametric tests of small samples often leads to incorrect P-values: examples from Animal Behaviour. Anim Behav 56:256-259

Pflugfelder O (1977) Wirtstierreaktionen auf Zooparasiten. Fischer Verlag Stuttgart, New York, pp 237-238

Raga JA (1992) Parasitismus bei den Pinnipedia. In: Robineau D, Duguy R, Robineau D (Hrsg.). Handbuch der Säugetiere Europas: Meeressäuger, Bd. 6, Teil II. Aula-Verlag, Wiesbaden, p 41-75

Ross PS, De Swart RL, Visser IKG, Vedder LJ, Murk W, Don Bowen W, Osterhaus ADME (1994) Relative immunocompetence of the newborn harbour seal, Phoca vitulina. Vet Immunol Immunopathol 42:331-348

Siebert U, Wünschmann A, Weiss R, Frank H, Benke H, Frese K (2001) Post-mortem findings in harbour porpoises (Phocoena phocoena) from the German North and Baltic Seas. J Comp Path 124:102-114

Siegel S, Castellan NJ (1988) Nonparametric Statistics for the Behavioural Sciences. McGraw-Hill, New York

Strauss V, Claussen D, Jäger M, Ising S, Schneider T, Stoye M (1991) The helminth fauna of the common seal (Phoca vitulina Linné, 1758) from the Wadden Sea in Lower Saxony. J Vet Med 38:641-648

Thompson PM, Corpe HM, Reid RJ (1998) Prevalence and intensity of the ectoparasite Echinophthirius horridus on harbour seals (Phoca vitulina): effects of host age and inter-annual variability in host food availability. Parasitology 117:393-403

Wünschmann A, Siebert U, Weiss R (1999) Rhizopusmycosis in a harbour porpoise from the Baltic Sea. J Wildl Dis 35(3):569-573

Wünschmann A, Siebert U, Frese K, Lockyer C, Heide-Jørgensen MP, Müller G, Baumgärtner W (2001) Evidence of infectious diseases in harbour porpoises (Phocoena phocoena) hunted in the waters of Greenland and by-caught in the German North Sea and Baltic Sea. Vet Rec 148:715-720

Zimmermann T, Nebel W (1975) Über Erkrankungen von Seehunden aus dem Gebiet der nordfriesischen Küste. Dtsch Tierärztl Wschr $82: 233-235$ 